\title{
Racial-Equity Policy as Leadership Practice: Using Social Practice Theory to Analyze Policy as Practice
}

\author{
Sue Feldman \\ Lewis and Clark College \\ U.S.A. \\ Ilana Winchester \\ Lewis and Clark College \\ U.S.A.
}

ABSTRACT: This, primarily theoretical, paper takes up the longstanding problem of the disconnection between education policy and leadership practice. The authors propose the use of social practice theory as a tool for educational leaders at the state, school district, and school levels, to eliminate the disconnection between policy design and leadership action. Using Oregon as an example, the authors illustrate a relationship between equity-policy design and leadership practice that may help identify weaknesses and strengths in equitypolicy designs and ultimately support better equity policy for leadership practice.

KEYWORDS: educational leadership, educational policy, institutionalized racism, racial equity, social practice theory

\author{
Background \\ Policy Implementation Challenges \\ Conceptualizing Policy as Practice \\ Policy Practice Illustrated \\ Practice of Policy Design \\ Practice in Policy Discourse \\ Equity-Policy Implementation Research \\ Conclusion \\ References \\ Author Contact
}

The purpose of this theoretical paper is to explore a relationship between equity-focused policy (e.g., policy aimed at eliminating racial disparity in education access and outcomes, policy aimed at equalizing access to STEM courses, and policy aimed at increasing dual language instruction) and equityfocused leadership practice. Using one school district in Oregon as an illustrative example, we analyze two racial equity policies as a likely source of equityfocused leadership. Using a social practice conceptual framework, we analyze the policies' constraints and affordances for leadership at the school and school 
district level. This paper illuminates policy challenges and potentially useful policy designs aimed at ending institutionalized racism in education. Policy designs alone will not end institutionalized racism, but locally designed equity policy may offer a leadership tool for deconstructing institutionalized racism.

\section{Background}

We begin with some background on equity policy in Oregon as a particular location for equity-focused leadership. Starting in the early 1990s, the state of Oregon saw steep growth in "minority" student populations. Forward thinking policymakers and education leaders in the state saw the parallel need to ready the school system to meet the learning needs of a diversifying student population. After earlier attempts in 1993 and 1995, State Senator Gordly, the first African American woman elected to the state senate, proposed a multicultural education bill in 1999 (Gordly, 1999). Gordly was concerned with the rise in Black-on-Black violence in Oregon. Drawing on what African American youth were describing as disenfranchisement in public schools, Gordly wanted to see schools teach a multicultural curriculum that could engage all the students, which the dominant culture curriculum was clearly not doing. "Exemplary curricula exist. What was lacking - and still is lacking - was a systematic way of identifying, connecting, sharing and delivering this curricula" (Gordly, 2004). This bill, although mostly exploratory, set in motion new considerations for education leadership. As reported by Oregon Department of Education staff at the time, what became immediately apparent to state, school district and school level leaders was not that they did not want to comply with the policy, but they did not know how. In 1999, the dominantly White state, school district and school leaders had not done this work before and were not only unsure what it required of them, but they were also concerned about how to prepare their mostly White teachers to use multicultural curricula.

In 2001, the Oregon University System (OUS) was asked by the state senate to conduct a review of state policies on cultural competence. The review suggested that, while the focus of SB103, 1999 was the implementation of multicultural curriculums, the focus of state and district leaders continued to be how to become culturally competent in order to understand what this work would require. Also in 2001, Oregon was awarded funds from the Wallace Foundation for the State Action for Education Leadership Project (SAELP). This project aimed to incentivize state development of a policy context to support school leaders learning to meet the new, demanding, and strict academic achievement expectations. In 2003, Oregon's SAELP team set its goals as (a) cultural competence and needs of diverse learners, and (b) academic proficiency. Here there is a hint of Senator Gordly's interest in creating schools that teach to the learning needs of diverse students. By this time, the reauthorization of the Federal Elementary and Secondary Education Act (ESEA) had redefined equity in education as all students having equal access to high quality learning 
experiences measured by state-wide student achievement tests. While public reporting of student achievement-test scores brought public scrutiny to the long standing racial disparities in education, under ESEA the particular concerns of multicultural education (e.g., Banks, 1994, 1995, 2002; Cross, 2003; DermanSparks \& Brunson-Phillips, 1997; Gay, 2000; Gay \& Howard, 2000; Gordon, 1995; Nieto, 1999, 2003) were largely ignored in favor of aligning standards and assessments to raise test scores to meet the new strict demands of public accountability.

In 2004, while racial disparities in academic achievement tests persisted in Oregon, state and district education leaders gathered for a cultural competency summit, in which they worked collaboratively to establish cultural competency standards for the state's school system. These standards were subsequently translated into both teacher and administrator licensing standards. In 2005, this collaboration extended to become the Oregon Leadership Network (OLN), for superintendents and their school and district leadership teams to continue to collaborate on equity-focused work in and across their districts. The mission of the OLN is to expand and transform the knowledge, will, skill, and capacity of educational leadership to focus on issues of educational equity so that each student achieves at the highest level. Currently, OLN reports 20 member school districts. The OLN member school districts include more than $40 \%$ of Oregon's student population. Though it is not yet the majority of students, OLN membership continues to grow. In 2012, the Oregon Education Investment Board (OEIB), a new state-level body tasked with strategically investing education funds to accomplish the state's education and employment goals, adopted an equity lens to be used as a framework for decision-making. School district leaders are encouraged to make explicit how their resource allocations and their policy and program priorities meet the expectations of the equity lens.

In 2014, there are no examples of school districts in Oregon with fully implemented multicultural curricula, as Senator Gordly had believed to be necessary if African American students were going to get the education they needed; however, there are observable practices, in multiple school districts, that provide evidence of efforts to demonstrate cultural competence. Oregon now has the only teaching and leadership standards that include expectations for cultural competence; it is the only state education system with an equity lens to guide decision making; it is the only state with a leadership network explicitly focused on supporting superintendents continuing to develop the skill, will, and capacity to improve equity in education. While racial disparities persist, and little effort has been made to transform the curriculum to be multicultural, under the leadership of OLN, there is a steady trickle of school boards authoring and adopting their own locally salient racial-equity policies. We began this project with a curiosity about what these local policies buy school and district leaders that is not already available in the policy landscape. Below we share what we have learned so far. 


\section{Policy Implementation Challenges}

There is no lack of equity-focused policy in education. It could be argued that the majority of education policy is concerned with making changes that address (in)equities inherent in the education environments, and yet inequity persists (e.g., Ingram \& Schneider, 1991; Kluger, 1975; Skarla, Scheurich, Johnson, \& Koschoreck, 2001; Yudof, Levin, Moran, Ryan, \& Bowmans, 2012). One contributing factor constraining policy may be the fact that education systems largely ignore the knowledge production value in studying their own policy implementation activity (e.g., Gherardi, 2006; Honig, 2006b; Yanow, 1996). Emphasis on research designs not sensitive to the on-the-ground interactions, where (in)equity in education is happening in real time, constrain research findings. Few school districts or state systems of education allocate resources for policy implementation research; instead, new policy is rolled out, underconceptualized and buffered or ignored as a source of leadership, leaving the system unaware of its own useful practices. In situations where policy implementation is studied, this research faces multiple challenges making it difficult to understand locally or more broadly what about a policy design or enactment affords leadership practice. To elaborate on some of the challenges of implementing education policy as leadership practice, we identify five problems in education policy implementation research: (a) over-attribution of failure to education policy; (b) false separation of policy and practice; (c) establishment of grounds for practice as evidence of policy implementation; (d) expectations for stable, sustained policy implementation; and (e) under-conceptualization of the learning required for implementation. Before we present the conceptual framework, we further elaborate these concerns in practical terms.

First, the solid portion of policy implementation research results in conclusions of failed policy (e.g., Anyon, 1997; Bell, 1987; Cohen \& Barnes, 1993; Cohen, McLaughlin, \& Talbert, 1993; Cohen, Moffitt, \& Goldin, 2007; Honig, 2006a; Odden, 1991; Orfield \& Eaton, 1996). While it is true that we have not succeeded in designing policy that has eliminated inherent inequities in education, no policy fails entirely. Policy implementation research has often been tied closely to program evaluation and implementation standards that were more political than practical, constraining the focus of the research and the resulting findings (Honig \& Hatch, 2003). Inadequate measures focused on outcomes far from the implementation action easily confuse lack of full implementation with failure. For example, it is not uncommon for non-research-trained legislators to require changes in student achievement scores as a measure of policy success, when student achievement is an indirect outcome at best and often so deeply nested in a complex array of variables it can not be accurately measured. And yet, to comply with policy makers' expectations, a measure is reported as failure. Second, a central feature in policy implementation research has been a perceived split between policy and practice (e.g., Ball \& Cohen, 1999; Burch, 2007; Cohen \& Hill, 2000; Cohen et al., 2007; McLaughlin, 1987; Varghese, 
2008; Weatherley \& Lipsky, 1977). Although there is literally nothing that happens in a classroom, school, or school district that is not touched by policy, practitioners at all levels of the education system are unlikely to differentiate between their practice and the policy(s) that shape it, suggesting, for practical purposes, that the dualism is false (Knapp \& Feldman, 2012; Knapp, Feldman, \& Yeh, 2013). This split can result in the evaluation of policy failure in situations where a practice focus may yield a different conclusion about the uses of policy on practices. Third, whatever the particular goals of a policy, the ultimate goal is to change practice, but it is difficult to establish what the evidence of the new practice should be. In the trend toward evidence-based decision making, there remain numerous questions about what evidence is, and how it is used (e.g., Barley, 1986; Coburn \& Honig, 2008; Coburn \& Talbert, 2006; Diamond \& Cooper, 2007; Firestone, 2007; Goren, 2012; Honig \& Venkateswaran, 2012; Little, 2012; Marsh, Pane, \& Hamilton, 2006). This contributes to poor decisions based on weak evidence and common misinterpretations (Feldman, 2010) about what is and is not working in a policy design. Fourth, while there is organizational value in policy as the declaration and documentation of organizational aims, tools, capacity, environments, and agreements, these trappings of clarity and specificity may create, for policy implementation researchers, the illusion of an endgame where there is none (Giddens, 1984; Schneider \& Ingram, 1990). Many policy aims elaborate a sustained stable-state outcome when in fact the accomplishment of the aim is not a sustained stable state. It is an on-going, continuously changing practice (Schneider \& Ingram, 1990). Finally, in order for a group of people in a school to accomplish something that a group of people at the state house or school district office have designed, it will require learning (Cohen \& Barnes, 1993; Penuel, Fishman, Cheng, \& Sabelli, 2011). The failure of many education reforms is the result of underestimating who needs to learn what, when, and how in order to do these new practices. To refocus policy implementation research, we draw on practice theory and social-learning theory to frame our approach to policy implementation research.

\section{Conceptualizing Policy as Practice}

Drawing on practice theories (e.g., Engestrom, Meittinen, \& Punamaki, 1999; Gherardi, 2006; Giddens, 1979; Orlikowski, 2002 ; Reckwitz, 2002; Yanow, 1996) and social learning theory (e.g., Brown, Collins, \& Duguid, 1998; Brown \& Duguid, 1991; Cole, John-Steiner, Scribner, \& Souberman, 1978; Drew \& Heritage, 1997; Hutchins, 1995; Hutchins, 2000; Lave \& Wenger, 1991; Rogoff, 1990; Wenger, 1998; Wertsch, 1991). The following conceptual framework is developed as a tool to analyze education policy as practice.

We use the idea of practice to mean "a way of accounting for the situated logic of activities across a wide array of contexts. Practice gets at the way individuals and groups engage in situated behaviors that are both constrained and enabled by existing structures. But which allow the person to exercise 
agency in the emerging situation" (Sutton \& Levinson, 2001, p. 3). We draw on Cook and Seely-Brown (1999) to further clarify a definition of practice:

Practice implies doing. Intuitively, it refers to things we do as individuals and as groups.... In common usage, "practice" can mean either to develop a competency through drill or rote actions as in "to practice the piano" or to exercise a competency as in "to practice medicine." The former suggests drill in preparation for doing the "real work," while the latter suggests the "real work" itself. In our use of the term, we mean doing real work: the practice of engineers, managers, physicians, woodworkers, etc. (in which, meanwhile, drill and other rote like activities can play an important part). For our purposes, then, we intend the term "practice" to refer to the coordinated activities of individuals and groups in doing their "real work" as it is informed by a particular organizational or group context. In this sense, we wish to distinguish practice from both behavior and action. Doing of any sort we call "behavior," while "action" we see as behavior imbued with meaning. By "practice," then, we refer to action informed by meaning drawn from a particular group context [emphasis added]. (Cook \& Seely-Brown, 1999, pp. 386-87)

This explanation of practice helps highlight three important ideas for understanding policy as practice: first, practice is both locally produced and interactive with broader organizational contexts; second, practice may be what one person does or groups of people do; and third, practice is a negotiation between agency and structure.

To build our conceptualization of policy as practice, we draw on three specific principles of practice theory: "(1) situated actions are consequential in the production of social life; (2) that dualisms [i.e., policy as separate from practice] are rejected as a way of theorizing and (3) that relations are mutually constitutive. These principles can not be taken singly, but implicate one another" (Feldman \& Orlikowski, 2011, p. 2042). To use these three principles of practice theory, we propose policy as situated action consequential in the production of social life. We reject the dualism of policy vs. practice and embrace the mutually constitutive nature of policy and practice in "the coordinated activities of individuals and groups in doing their "real work" as it is informed by a particular organizational or group context" [emphasis added]. (Cook \& SeelyBrown, 1999, pp. 386-387)

\section{Policy Practice Illustrated}

In the analysis and discussion below, we focus on equity policy from one school district in Oregon. There are other examples of locally designed equity polices in Oregon but the Tigard-Tualatin school district is seen as the frontrunner for this work. The superintendent, in 2010, was among the first in the Oregon Leadership Network to pursue a locally defined equity framework and 
policy with his school board. We did not choose Tigard-Tualatin as exemplary policy, although other school districts have used the Tigard-Tualatin policy practice as an example to guide their own local policy practice. As our example analysis will show, there are limitations in these policy practices that produce limitations in leadership practice. That said, there are interesting and potentially important things to be gained from understanding these policies as practice.

Below, we present two contrasting equity-focused policies, from this school district, developed in two points in time, to test our theory that policy is practiced in three ways: (a) practice of policy design, (b) practice in policy discourse, and (c) practicing policy.

\section{Practice of Policy Design}

In 2013, when the Tigard-Tualatin school district adopted their current version of racial-equity policy, they already had, in their school board policy book, an equal opportunity policy:

Equitable educational opportunities shall be provided to all students regardless of national origin, age, disability, marital or parental status, race, color, religion, sex or sexual orientation. Further, no student will be excluded from participating in, denied the benefits of, or subjected to discrimination under any educational program or activity conducted by the district. The Board and staff will be guided by equitable educational opportunity practices in making decisions relating to budget allocations, providing school facilities, selection of materials and equipment, determination of curriculum and adoption of regulations affecting students. The superintendent will designate at least one employee to coordinate the District's efforts to comply with and carry out its responsibilities under Title IX. The Title IX coordinator will investigate complaints communicated to the district alleging noncompliance with Title IX. The name, address and telephone number of this coordinator will be provided to all students and employees. The Board will adopt and the district will publish grievance procedures providing for prompt and equitable resolution of student and employee complaints under Title IX. (Tigard Tualatin School District, 2013)

This policy covers the legal ground of equal educational opportunity. It provides for students' rights to equitable educational opportunity, addresses discrimination and the protected classes, and explains the adults' responsibilities to use equitable educational practices. Why did the district need or want an additional policy that explains similar expectations?

From our practice theory perspective, even if the language in the policy above and the one presented below covers similar concerns, the practice of designing the policy is substantially different. The policy above reads like most of the equal opportunity policy around the country, boilerplate policy generated from one of the many professional associations that draft policy and send it to school 
board directors to adopt. Our speculation is that the practice of designing this policy happened far from the school district. In fact, in a recent equity-policy workshop held at Lewis and Clark College, in Portland, Oregon, superintendents from around the state confirmed that they had adopted the identical policy. In other words, they did not engage in the design of the policy, but instead in the practice of adopting the policy. This practice involves a discussion with the school board, a limited group of stakeholders, and a majority ruled vote of the school board. This is not unusual policy design practice. What does seem to be unusual is the local practice of policy design.

To see how the practice of policy design might matter, we now present a contrasting example of policy design practice. In 2010, the Tigard-Tualatin School District published an equity framework document that explains changes in equity practice and changes in patterns of participation intended and accomplished by the school district. The framework reads as a report not just to the school board, but to the staff and the community and the larger public. Unlike the school board accepting boilerplate policy for compliance purposes, which involves few people outside of the school board themselves to engage in deliberative discussions, this work spread over three years, with more than 150 staff members participating in at least five days of training in "courageous conversation." It's easy to imagine the difference in practice of a short discussion during a board meeting with a small, select group of participants voting to use a policy developed by others, and the extensive practice of training the entire staff to listen to multiple perspectives and follow pro-social norms to discuss race, racism, and institutionalized racism. These conversations intend to constitute a new form of interaction, re-norming the organization to identify and interrupt racism expressed in dialogue. As a cultural tool, the equity framework documents changes in the district vision, norms, and organizational expectations for "equitable educational practices." Equity was no longer defined only by federal law, but was now defined by themselves and their education consultant partner, The Pacific Educational Group (PEG):

Equity is: Raising the achievement of all students while narrowing the gaps between the highest and lowest performing students and eliminating the disproportional number and racial predictability of the student groups that occupy the highest and lowest achievement categories. (Glenn Singleton as cited in Tigard-Tualatin Equity Framework, 2010)

The language for the 2013 Tigard-Tualatin equity policy reads as follows:

The Tigard Tualatin School District Board of Directors is committed to ensuring that our schools work for each student. We believe that in order to be successful we must be intentional about improving the performance and raising the achievement of each student; narrow the gap between the highest and lowest performing students; and eliminate the racial predictability and disproportionality of which students are in the highest and lowest achieving groups. 
Tigard Tualatin School District is a community of learners passionately committed to equity and excellence for everyone touched by our school district.

We believe:

1. Children of every race can and will learn at the highest levels when all staff ensure equitable access and hold every student to high expectations.

2. Every adult employed or volunteering in the Tigard-Tualatin School District must have the moral imperative and skill to eliminate racial disparities.

3. The Tigard-Tualatin School District will only be excellent when families of color are empowered as equal partners to influence, inform, and impact decisions throughout our school system.

4. Our community will be able to reach its full potential only when TTSD educates students of all races to the highest levels.

5. To accomplish this goal we will use racially disaggregated data to inform all district decision-making and instruction.

6. Expect all TTSD staff to learn and use the Courageous Conversation Protocol so we continuously improve our will, skill, knowledge and capacity to eliminate racial disparities in our district.

7. Involve members of our community who are racially representative of our district and honor their multiple racial and cultural perspectives.

8. Hold one another mutually accountable for examining our policies, practices and programs for racial biases and eliminating racial disparities in our district wherever they are found.

9. Strive for continuous growth in all we do by building and supporting a district-wide, equity-focused professional learning organization and culture. (Tigard-Tualatin Equity Policy, 2013)

The first level of analyzing policy practice focuses on the practice of designing policy. Comparing these two polices helps illustrate some of the differences in practices of policy making. We are not suggesting that the practice determines whether one policy produces a better leadership tool than another. We are instead illustrating that even at the level of policy design, the actions of the school board, and the actions of the whole staff, are consequential in the production of social life of the district, that the dualism of policy as separate from practice does not hold true, but instead the practice of making a policy is a practice and the practice is mutually constitutive. In other words the practice of making the policy is reflected in the affordances and constraints of the policy itself. Moving to the second level of analysis, practice in policy discourse, further illustrates these principles of social practice. 


\section{Practice in Policy Discourse}

Finding the practice in the discourse of the policy requires analyzing the policy as text. Analyzing the practices contained in the text of the Tigard-Tualatin Equal Educational Opportunity policy, we found seven possible practices:

1. Equitable educational opportunities shall be provided;

2. No student will be excluded from participating in, denied the benefits, subjected to discrimination;

3. The Board and staff will be guided, making decisions;

4. The superintendent will designate, coordinate, comply, carry out its responsibilities under Title IX;

5. The contact information of the Title IX coordinator will be provided to all students and employees;

6. The Board will adopt; and

7. The district will publish grievance procedures.

The practices in this policy require only two actors to enact this policy: the superintendent and the designee. Even though this policy is an equal educational opportunity policy, it begins with the word equitable. The conflation of equality and equity is confusing, given how different these constructs are. Is the district supposed to provide the same educational opportunities, as equal opportunity would suggest, or different opportunities, as equitable opportunities suggests? From the first word, the practice of allocating opportunity is ambiguous. Additionally, the first practice, "Equitable educational opportunities shall be provided," does not clarify or specify what constitutes opportunity. The second practice, "will not be excluded or denied benefits," is proposed in terms of what not to do, rather than what to do, also making it difficult to practice. The rest of the practices described in the policy text relate to responding to complaints. This positions the district on the defensive. Imagine if a student or family made a claim against the district for racial discrimination. The practices available to school leaders, under this policy, are to do vague and undefined practices, or to participate in an investigation of discrimination. No educator, in 2013, is going to admit to discrimination, making this approach to practicing equitable education highly unproductive, if not overly adversarial (Pollack, 2008, Reardon \& Owens, 2013).

Analyzing the list of practices in the locally designed, 2013 equity-policy, offers an interesting contrast. We found 11 practices in our analysis of the practices in this policy text:

1. All staff ensure equitable access;

2. Hold every student to high expectations; 
3. Every adult employed or volunteering must have the moral imperative and skill to eliminate racial disparities;

4. Families of color are empowered as equal partners to influence, inform, and impact decisions throughout our school system;

5. TTSD educates students of all races to the highest levels;

6. Use racially disaggregated data to inform all district decision-making and instruction;

7. Expect all TTSD staff to learn and use the Courageous Conversation Protocol;

8. Continuously improve our will, skill, knowledge, and capacity to eliminate racial disparities in our district;

9. Involve members of our community who are racially representative of our district and honor their multiple racial and cultural perspectives;

10. Hold one another mutually accountable for examining our policies, practices, and programs for racial biases and eliminating racial disparities in our district wherever they are found; and

\section{Strive for continuous growth.}

This list includes pro-active, shared, specific, on-going, practices expected of all the adults across the school district. Some of these practices, like having a moral imperative, are aspirational, while others, including the fourth practice, "Families of color are empowered as equal partners to influence, inform, and impact decisions throughout our school system," define specific changes in patterns of participation in decision-making. In this policy, there are expectations and some directions for adults to make changes in their practice including, holding one another mutually accountable for examining policies, practices, and programs for racial biases and eliminating racial disparities in the district wherever they are found. It is unusual in education environments for the adults to hold each other accountable especially about socially controversial topics. It is more common for professional practice to favor the "tyranny of nice" and the expectations that being professional means not upsetting a teacher, not talking directly about another teacher's practices, and not raising questions about why some students excel in some classrooms and others do not. Establishing an expectation that all the educators, from administrators to teachers to families, share the responsibility to talk about race, hold each other accountable for racial disparities, find and point out policies that maintain racialized inequities and continue to develop their skill, will, knowledge, and capacity to eliminate racial disparities, changes practice for everyone, not in response to a complaint, but pro-actively as a matter of what it means to do the daily work of education in this district. At this second level of analysis, it is again possible to see how the practices described in the policy are consequential in the production of the social life of the school district. According to the second policy, equity is constituted in conversation, deliberation, and argumentation. Equity is not settled or agreed upon; it is produced in these forms of interaction that did not exist as district 
practice prior to 2010. At this level of analysis again, there is no separation of policy and practice. The policy is the description of practice, whether ideational or concrete, and these practices constitute and are constituted by the policy. We now turn to the third level of analysis, practicing policy to consider how the practice of making policy and the practice in policy discourse contribute to practicing the policy.

\section{Practicing Policy}

Practicing ideas that come from courtrooms or legislative bodies far from the school district office or the schoolhouse is challenging (Bell, 1987, 2004; Cohen \& Barnes, 1993). Although adopting the ideas without practicing them has a certain efficiency appeal, in the case of "equitable educational practices" it seems ultimately not to be an efficient process, but one that requires considerable practice.

While it is unlikely for school districts to have provable claims of discrimination, they are highly likely to have significant racial disparity in academic achievement and academic program participation with disproportional participation of minority students in academic programs that produce collegeready transcripts. Clearly, equal opportunity policies have not eliminated discrimination, even if it is difficult to prove, in these times. Taking a socio-cultural approach to addressing discriminatory practices, as the second policy does, rather than a legal approach, as the first policy does, may offer at least a broader approach to engaging the whole staff in the work of defining and discussing what equitable educational practice is. Leadership for the equal opportunity policy might require following through on appointing someone to handle complaints, reporting to the school board if there were complaints, and responding to requests for public records and other evidence related to a complaint. The policy does not require training of all staff in understanding equity related to civil rights laws, but it is conceivable that leadership might include training people about civil rights complaints, how to avoid them, and how to respond to them. Beyond that, there is not a lot of leadership direction for this policy.

The locally designed racial-equity policy offers much more direction and support for practicing the policy. The leadership opportunities include providing for ongoing conversations. Equity is positioned as a contested idea that needs to be talked about and thought about and learned about. Even with clear documentation that holds and authenticates the commitment to achieving the goals of eliminating racial disparities in academic achievement, leadership for this policy necessarily constitutes what this means in the daily practice of the organization. The situated actions of all the adults are considered consequential for the elimination of racial disparities. As the policy describes, the adults have responsibilities to each other, to learning, and to eliminating racial disparities in academic achievement. In other words, as defined by the equity policy, this is not the sole work of a positional leader who knows what to do. Quite the opposite, it 
is pointing to leadership constituted in public learning, examining programs, policies, and practices that produce racial disparity, and producing the results by continuous skill, will, knowledge, and capacity building.

Taking these two policies side by side, it is interesting to see how clearly different leadership looks for accomplishing the different goals in these policies. Before locally crafted equity policy emerged in Tigard-Tualatin School District, equity-focused leadership could have been fully successful if it was off the radar, unless or until there was a civil rights complaint, if the complaints were few and if the district were exonerated no matter what the complaint. Contrast that to leadership for the sort of practices expected in this locally crafted racial-equity policy, which might require constantly engaging with equity issues and on-going learning, sharing decision-making and responsibility, deconstructing long standing programs, reallocating resources, standing up for fairness in unpopular settings, asking contentious questions about race, and ensuring that this level of leadership is spread across the whole organization, not held by a positional leader. The practices are the same for teachers, principals, coaches, district office directors and the superintendent. Given the significant differences in leadership between equity-focused leadership guided by compliance expectations and equity-focused leadership guided by engaged participation in courageous conversations about race, the statewide work on cultural competence has perhaps been necessary, although insufficient.

This third level of analysis also demonstrates the three principles of social practice theory:

1. Situated actions are consequential in the production of social life;

2. Dualisms [i.e., policy as separate from practice] are rejected;

3. Relations are mutually constitutive.

Policy contexts are consequential in the production of leadership practice and the social life of the school. If policy describes leadership practice as designating someone to investigate claims of discrimination, it will generate a different social life in the school than facilitating ongoing conversations about race in schools.

So far we have illustrated how three principles of social-practice theory can offer a new lens for analyzing policy as three levels of practice. The last task is to address how this might improve education policy research.

\section{Equity-Policy Implementation Research}

Above, we have briefly illustrated how using a social practice/learning theory to analyze policy as practice might help delineate differences in the support and direction this policy might provide for leadership action. This conceptual framework may help us establish where to look for evidence of policy practice and help establish the forms of leadership that may be afforded or 
constrained in the policy design and policy discourse. While it is interesting how clearly and how starkly the differences in these two equity-focused policies direct and afford leadership, there is much further work to be done to establish how to study these practices in action.

In much education policy research, the policy states what is expected and researchers are dispatched to evaluate the extent to which there is evidence that the policy goals have been met. This approach takes for granted that what needs to change is known, how to realize the change is known, and how to evaluate the change is known. Looking at these two policies side by side, what researchers would be focused on, if they were assigned one of these policies rather than the other, would be different. For the equal opportunity policy, the concern might be the number of complaints, the type of complaints, the execution of the investigation, and the pattern of findings, and yet none of this tells the district how or what they are actually doing to generate (in)equity. For the racial equity policy, a policy implementation researcher dispatched to evaluate the policy implementation might search for who is learning what, when, and how in their efforts to accomplish the practices outlined in the policy. This policy design suggests a focus on an on-going state of learning, examining, questioning, arguing and deciding as well as considering where, when, how often, how intensively, and how widespread these practices are. Equity policy should be of central importance to education policy researchers because, in fact, we don't know how to eliminate racial disparities in education. Our best chance, as the Oregon leaders proposed, might be to try to learn as they go, starting with understanding the obstacles they bring to accomplishing the work.

Social learning/practice theory helps highlight what might be the next generation of equity-policy implementation research. A first step may be for school districts to invest in producing local knowledge for local purposes, and then to invest in the production of new insights and generalizable knowledge for the field from their emergent practices. To understand what is generated in these local, confusing, rough, socially messy, and unpredictable interactions between people with different interests and needs to accomplish something not yet known, is likely to require research methods sensitive to learning. Engestrom (2001) described it this way:

Standard theories of learning are focused on processes where a subject (traditionally an individual, more recently possibly an organization) acquires some identifiable knowledge or skills in such a way that a corresponding, relatively little change in the behavior of the subject may be observed. It is a self-evident presupposition that the knowledge to be acquired is itself stable and reasonably well defined. There is a competent "teacher" who knows what is to be learned. The problem is that much of the most intriguing kinds of learning in work organizations violates this presupposition. People and organizations are all the time learning something that is not stable, not even defined or understood ahead of time. In important transformations of our personal lives and organizational practices, we must learn new forms of activity, which are not yet there. 
They are literally learned as they are being created. There is no competent teacher. Standard learning theories have little to offer if one wants to understand these processes. (pp. 137-38)

From this perspective, it is not a failure not to know how to eliminate racial disparities in education; it is a failure not to put in place practices that afford learning from your local practice to improve your local practice.

\section{Conclusion}

Senator Gordly had a vision for transforming Oregon's schools into multicultural educational environments. SB103,1999 laid groundwork to explore, examine, review, and report on the current polices and practices related to multicultural education. The policy had a focus on learning about what the state was currently doing, what else the state might do, and what it might look like to transform Oregon's education system with a multicultural curriculum. Oregon's school leaders, at that time and now, took a learning approach to exploring their own cultural competence as the first step to learning how to approach multicultural education. Although these learning agendas had different interests, they hold in common learning what we do not yet know how to do as a significant policy practice. What they lacked then and continue to lack is a research agenda that produces local knowledge for local purposes and generalizable knowledge for the field to continue to learn how to eliminate inherent inequity in education.

Engestrom (2001) offers this, from his own learning-focused research. Although his study was of health care providers and not educators, the insight is remarkably well fit to equity-focused work:

This learning challenge could not be met by training individual practitioners... to adopt some new skills and knowledge. The issue at stake was organizational, not resolvable by the sum total of separate individuals. On the other hand, there was no mythical collective subject that we would approach and push to take charge of the transformation. Top-down commands and guidelines are of little value when the management does not know what the content of such directives should be.... If we want to successfully confront the various actors involved in [education] we must be able to touch and trigger some internal tensions and dynamics in their respective institutional contexts, dynamics that can energize a serious learning effort on their part. In our case, learning needs to occur in a changing mosaic of interconnected activity systems which are energized by their own inner contradictions. (p. 139)

From this point of view, the Tigard-Tualatin School District Racial Equity Policy has the potential to support the on-going learning required to accomplish work that is yet unknown, particularly if they find a way to learn from their practices to improve their practices. 


\section{References}

Anyon, J. (1997). Ghetto schooling: A political economy of urban educational reform. New York, NY: Teachers College Press.

Ball, D., \& Cohen, D. (1999). Developing practice, developing practitioners: toward a practice-based theory of professional education. In L. DarlingHamond, \& G. Sykes (Eds.), Teaching as the learning profession: Handbook of policy and practice (pp. 1-32). San Francisco, CA: JosseyBass.

Banks, J. (1994). An introduction to multicultrual education. Needham Heights. Boston, MA: Allyn \& Bacon.

Banks, J. (1995). Multicultural education and curriculum transformation. Journal of Negro Education, 64(4), 390-400.

Banks, J. (2002). Race, knowledge construction, and education in the USA: Lessons from history. Race Ethnicity and Education, 5(1), 7-27.

Barley, S. R. (1986). Technology as an occasion for structuring: Evidence from observations of CT scanners and the social order of radiology departments. Administrative Science Quarterly, 31, 78-108.

Bell, D. (1987). And we are not saved. New York, NY: Basic Books.

Bell, D. (2004). Silent covenants: Brown V. Board of Education and the unfulfilled hopes of racial reform. Oxford, UK: Oxford Press.

Brown, J. S., Collins, A., \& Duguid, P. (1998). Situated cognition and the culutre of learning. Education Researcher, 18(1), 32-42.

Brown, J. S., \& Duguid, P. (1991). Organizational learning and communites of practice: Toward a unified view of working, learning and innovation. Organizational Sciences, 2(1), 40-57.

Burch, P. (2007). Educational policy and practice from the perspective of institutional theory: Crafting a wider lens. Educational Researcher, 36(2), 84-95.

Coburn, C., \& Honig, M. (2008). Evidence-based decision making in school district central offices: Toward a policy and research agenda. Education Policy, 22(4), 578-608.

Coburn, C., \& Talbert, J.E. (2006). Conceptions of evidence use in school districts: Mapping the terrain. American Journal of Education, 112(4), 469495.

Cohen, D., \& Barnes, C. (1993). Pedagogy and policy. In M. McLoughlin, \& J. Talbert (Eds.).Teaching For Understanding (pp. 207-239) San Francisco, CA: Jossey-Bass. 
Cohen, D., \& Hill, H. (2000). Instructional policy and classroom performance: The mathematics reform in California. Teachers College Record, 102, 294343.

Cohen, D., McLaughlin, M., \& Talbert, J. (1993). Teaching for understanding: Challenges of policy and practice. San Francisco, CA: Jossey Bass.

Cohen, D., Moffitt, S., \& Goldin, S. (2007). Policy and practice: The dilemma. American Journal of Education, 113(4), 515-148.

Cole, M., John-Steiner, V., Scribner, S., \& Souberman, E. (1978). Mind in society: The development of higher psychological processes. Cambridge, MA: Harvard University Press.

Cook, S., \& Seely-Brown, J. (1999). Bridging epistemologies. Organization Science, 10(4), 381-400.

Cross, B. E. (2003). Learning or unlearning racism: Transferring teacher education curriculum to classroom practices. Theory Into Practice, 42(3), 203-209.

Derman-Sparks, L., \& Brunson-Phillips, C. (1997). Teaching and learning antiracism. New York, NY: Teachers College Press.

Diamond, J. B., \& Cooper, K. (2007). The use of testing data in urban elementary schools: Some lessons from Chicago. Yearbook of the National Society for the Study of Education.106(1), 241-263.

Drew, P., \& Heritage, J. C. (1997). Talk at work. Cambridge, MA: Cambridge University Press.

Engestrom, Y. (2001). Expansive learning at work; Toward an activity theoretical reconceptualization. Journal of Education and Work, 14(1), 133-156.

Engestrom, Y., Meittinen, R., \& Punamaki, R. L. (1999). Perspectives on activity theory. Cambridge, MA: Cambridge Press.

Feldman, M.S., \& Orlikowski, W.J. (2011). Theorizing practice and practicing theory. Organization Science, 22(5), 1240-1253. doi: 10.1287/orsc.1100.0612

Feldman, S. (2010). Inquiry-focused reform: How teachers learn new practices from their current practice (Unpublished doctoral dissertation). University of Washington: Seattle, WA.

Firestone, W. A. (2007). Culture and processes affecting data use in school districts. Evidence and Decision Making, 132-154.

Gay, G. (2000). Culturally responsive teaching: Theory, research, and practice. New York, NY: Teachers College Press.

Gay, G., \& Howard, T.C. (2000). Multicultural teacher education for the 21st century. Teacher Educator, 36(1), 1-16.

Gherardi, S. (2006). Organizational knowledge: The texture of workplace learning. Malden, MA: Blackwell Publishing. 
Giddens, A. (1979). Central problem in social theory. Berkeley, CA: University of California Press.

Giddens, A. (1984). The constitution of society: Outline of a theory of structuration. Berkeley, CA: University of California Press.

Gordly, A. Chapter 1042 Oregon Laws (1999)

Gordly, A. (2004). We need to know our history. Retrieved from http://www.nytimes.com/ref/college/coll-opinions-gordly.html

Gordon, B. (1995). Knowledge construction, competing critical theories, and education in J. Banks (Ed.), International handbook of research on multicultural education (pp. 184-199). New York, NY: Macmillian.

Goren, P. (2012). Data, data, and more data-What's an educator to do? American Journal of Education, 118(2), 233-237.

Honig, M. (2006a). Complexity and policy implementation: Challenges and opportunities for the field. In M. Honig (Ed.), New directions in education policy implementation: Confronting complexity (pp. 1-24). Albany, NY: The State University of New York Press.

Honig, M. (2006b). New directions in education policy implementation: Confronting complexity. Albany, NY: The State University of New York Press.

Honig, M., \& Hatch, T. (2003). Crafting coherence: How schools strategically manage multiple, external demands. Educational Researcher, 33(8), 1630.

Honig, M., \& Venkateswaran, N. (2012). School-central office relationships in evidence use: Understanding evidence use as a systems problem. American Journal of Education, 118(2), 199-222.

Hutchins, E. (1995). How a cockpit remembers. Cognitive Science, 19, 265-288.

Hutchins, E. (2000). Cognition in the wild. Cambridge, MA: Massachusetts Institute of Technology.

Ingram, H., \& Schneider, A. (1991). The choice of target population. Adminstration and Society, 23(3) 333-356.

Kluger, R. (1975). Simple justice. New York, NY: Vintage Books.

Knapp, M., \& Feldman, S. (2012). Managing the intersection of internal and external accountability: Challenge for urban school leadership in the United States. Journal of Educational Administration, 50(5), 666-694.

Knapp, M.S., Feldman, S., \& Yeh, T.L. (2013). Learning-focused leadership in urban high schools: Response to demanding environments. Journal of School Leadership, 23(2), 252-285.

Lave, J., \& Wenger, E. (1991). Situated peripheral participation. Cambridge, UK: Cambridge University Press. 
Little, J. (2012). Understanding data use practice among teachers: The contribution of micro-process studies. American Journal of Education, 118(2), 143-166.

Marsh, J. A., Pane, J. F., \& Hamilton, L. S. (2006). Making sense of data-driven decision making in Education: Evidence from recent RAND research. Santa Monica, CA: RAND.

McLaughlin, M. (1987). Learning from experience: Lessons from policy implementation. Educational Evaluation and Policy Analysis, 9(2), 171178.

Nieto, S. (1999). The Light in their eyes: Creating multicultural learning communities. New York, NY: Teachers College Press.

Nieto, S. (2003). Affirming diversity: The sociopolitical context of multicultural education ( $4^{\text {th }}$ ed.) New York, NY: Longman.

Odden, A. (1991). Education policy implementation. Albany, NY: State University of New York Press.

Orfield, G., \& Eaton, S. (1996). Dismantling desegregation. New York, NY: Norton.

Orlikowski, W. ( 2002 ). Knowing in practice: Enacting a collective capability in distributed organizing. Organizational Science, 13(3), 249-273.

Penuel, W., Fishman, B., Cheng, B., \& Sabelli, N. (2011). Organizing research and development at the intersection of learning, implementation and design. Educational Researcher, 40(7), 331-337.

Pollack, M. (2008). Because of race: How Americans debate harm and opportunity in our schools. Princeton, NJ: Princeton University Press.

Reardon, S. F., \& Owens, A. (2013). Sixty years after Brown: Trends and consequences of school segregation. Annual Review of Sociology, 39, 143. doi: 10.1146/annurev-soc-071913-043152

Reckwitz, A. (2002). Toward a theory of social practice: A development in culturalist theorizing. European Journal of Social Theory, 5(2), 243-263.

Rogoff, B. (1990). Apprenticeship in thinking: Cognitive development in social context. Oxford, UK: Oxford Press.

Schneider, A., \& Ingram, H. (1990). Behavioral assumptions of policy tools. Journal of Politics, 52, 510-529.

Skarla, L., Scheurich, J., Johnson, J., \& Koschoreck, J. (2001). Accountability for equity: Can state policy leverage social justice? International Journal in Education, 4(2), 237-260.

Sutton, M., \& Levinson, B. (2001). Policy as practice:Toward a comparative socialcultural analysis of educational policy. Westport, CT: Ablex Publishing. 
Tigard-Tualatin Equity Framework (2010). Retrieved from http://www.ttsdschools.org/pages/ttsd/About Us/District Equity Work

Varghese, M. (2008). Using cultural models to unravel how bilingual teachers enact language policies. Language and Education, 22(5), 289-306.

Weatherley, R., \& Lipsky, M. (1977). Street level bureaucrats and institutional innovations: Implementing special-education reform. Harvard Education Review, 47(2), 171- 197.

Wenger, E. (1998). Communities of practice: Learning meaning and identity. Cambridge, UK: Cambridge Press.

Wertsch, J. (1991). Voices of the mind. Cambridge, MA: Harvard University Press.

Yanow, D. (1996). How does a policy mean? Interpreting policy and organizational actions. Washington DC: Georgetown University Press.

Yudof, M., Levin, B.B., Moran, R., Ryan, J., \& Bowmans, K. (2012). Educational Policy and the Law ( $5^{\text {th }}$ ed.). Belmont, CA: Wadsworth Cengage Learning.

\section{Author Contact}

Sue Feldman (corresponding author): feldmans@lclark.edu

Lewis and Clark College, Graduate School of Education, 0615 SW Palatine

Hill Rd, Portland, OR 97219, U.S.A.

Ilana Winchester: ilanaw@Iclark.edu

Lewis and Clark College, 0615 SW Palatine Hill Rd, Portland, OR 97219, U.S.A. 